IRA-International Journal of Applied Sciences ISSN 2455-4499; Vol.09, Issue 03 (December 2017)

Pg. no. 29-35

Institute of Research Advances

https://research-advances.org/index.php/IRAJAS

\title{
Optimization of Total Phenolics Content and Total Antioxidant Activity of Black Tea Using Response Surface Methodology
}

Tah Clovis Tiku ${ }^{1}$, Feumba Dibanda Romelle ${ }^{2}$, Yadang Germaine ${ }^{2}$, Nyobe Emillienne Carine ${ }^{2}$, Achegui Nestor ${ }^{2}$, Medoua Nama Gabriel², Mbofung Carl Moses ${ }^{1}$

${ }^{1}$ College of Technology, University of Bamenda, Cameroon.

${ }^{2}$ Food and Nutrition Research Centre, Institute of Medical Research and Medicinal Plants Studies, Cameroon.

Type of Review: Peer Reviewed.

DOI: http://dx.doi.org/10.21013/jas.v9.n3.p1

\section{How to cite this paper:}

Tiku, T.C., Romelle, F.D., Germaine, Y., Carine, N.E., Nestor, A., Gabriel, M.N., Moses, M.C. (2017). Optimization of Total Phenolics Content and Total Antioxidant Activity of Black Tea Using Response Surface Methodology. IRA International Journal of Applied Sciences (ISSN 2455-4499), 9(3), 29-35. doi:http://dx.doi.org/10.21013/jas.v9.n3.p1

(C) Institute of Research Advances.

\section{$($ (c) $)$ BY-NC}

This work is licensed under a Creative Commons Attribution-Non Commercial 4.0 International License subject to proper citation to the publication source of the work.

Disclaimer: The scholarly papers as reviewed and published by the Institute of Research Advances (IRA) are the views and opinions of their respective authors and are not the views or opinions of the IRA. The IRA disclaims of any harm or loss caused due to the published content to any party.

Institute of Research Advances is an institutional publisher member of Publishers Inter Linking Association Inc. (PILA-CrossRef), USA. The institute is an institutional signatory to the Budapest Open Access Initiative, Hungary advocating the open access of scientific and scholarly knowledge. The Institute is a registered content provider under Open Access Initiative Protocol for Metadata Harvesting (OAI-PMH).

The journal is indexed \& included in CAS Source Index of Chemical Abstracts Service of American Chemical Society (USA), WorldCat Discovery Service (USA), CrossRef Metadata Search (USA), WorldCat (USA), OCLC (USA), Open J-Gate (India), EZB (Germany) Scilit (Switzerland), Airiti (China), Bielefeld Academic Search Engine (BASE) of Bielefeld University, Germany, PKP Index of Simon Fraser University, Canada. 


\begin{abstract}
Response surface methodology was used to optimize the fermentation conditions for the total phenolics content and antioxidant activity of black tea (Camellia sinensis). Fresh tea leaves were fermented following a rotatable central composite design of eleven experiments replicated thrice. The minimum and maximum fermentation time and temperature were respectively of $1-3 \mathrm{~h}$ and $30-40{ }^{\circ} \mathrm{C}$. The results demonstrated that fermentation time and temperature significantly affect the total phenolics content and antioxidant activity of black tea. The optimum fermentation conditions for the present study were at $36{ }^{\circ} \mathrm{C}$ for $35 \mathrm{~min}$ which the values for total phenolics content and total antioxidant activity were $38.99 \mathrm{~g}$ GAE/100 $\mathrm{g} \mathrm{dw}$ and $19.74 \mathrm{mg}$ VitC Eq/100 $\mathrm{g} \mathrm{dw}$, respectively. Antioxidant activity was strongly correlated with total phenolics content of black tea.
\end{abstract}

Keywords: Optimization, Response surface methodology, Total phenolics content, Total antioxidant activity, Fermentation, Black tea

\title{
Introduction
}

Tea is one of the most popular and lowest cost beverages in the world and ranks second to water [1]. Tea is a major source of phenolic compounds in human diet. These compounds constitute up to $30 \%$ of the tea solids by weight [2]. Recently, tea is considered as a functional food thanks to its high phenolics content and their reported beneficial effects on human health, in particularly as antioxidants [3]. Essentially three main types of Camellia tea are produced annually; black tea (78\%), green tea (20\%), and $2 \%$ which is oolong tea [4].

During black tea processing, fermentation is a critical step. The fermentation stage involves an enzyme-catalysed oxidative reaction to the colored phenolic compounds [5]. The brown colored pigments formed during the fermentation process which give black tea its characteristic color and taste are mostly theaflavins and thearubbigins, the products of phenolics oxidation [6]. The significant reduction of phenolic compounds during black tea production affects the antioxidant properties of the resulting product [7]. This study aims to optimize fermentations conditions of black tea in order to have a black tea with maximum phenolics and antioxidant property.

\section{Materials and Methods}

\section{Procurement of tea leaves}

The biological material was made of fresh tea leaves (Camellia sinensis) that were plucked and collected from the Munjung section of Ndawara Highlands Tea Estate (NHTE), North-West Region of Cameroon.

\section{Black tea processing}

\section{Withering of tea leaves}

Fresh tea leaves (86\% moisture content) were allowed to wither in order to provide tea leaves with a moisture content of $75 \%$.

\section{Crushing of tea leaves}

Withered tea leaves $(15 \mathrm{~g})$ were introduced in a domestic grinder and crushed for $8 \mathrm{~s}$. The crushed tea leaves were scattered as a uniform thin layer of $2 \mathrm{~mm}$ on a $10 \times 10 \mathrm{~cm}$ stainless tray prior to fermentation.

\section{Experimental design for fermentation of tea leaves}

In order to assess the effect of fermentation temperature and time on the level of total phenolic compounds and the total antioxidant activity, a full factorial design $\left(3^{2}\right)$ was applied and three replicates in the center point were added to the experiment to fit the surface plot for the responses and to estimate the pure error of the multiple regression models [10], totaling 11 runs as displayed in table 1. So, crushed tea leaves were allowed to oxidize in a pre-heated incubator settled at the various couples of temperature /time as defined by the experimental design (Table 2). 
Table 1. Coded and decoded levels of independent variables used in the RSM design

\begin{tabular}{llrlllc}
\hline \multirow{2}{*}{ Independent variables } & & \multicolumn{5}{c}{ Levels } \\
\cline { 3 - 7 } & Symbols & -1.414 & -1 & 0 & +1 & +1.414 \\
\hline Fermentation time (min) & $\mathrm{X}_{1}$ & 0.6 & 1.0 & 2.0 & 3.0 & 3.4 \\
\hline Fermentation temperature $\left({ }^{\circ} \mathrm{C}\right)$ & $\mathrm{X}_{2}$ & 28 & 30 & 35 & 40 & 42 \\
\hline
\end{tabular}

\section{Drying of black tea}

Fermented tea leaves were dried at $120^{\circ} \mathrm{C}$ for $27 \mathrm{~min}$. Dried tea samples were allowed to cool at room temperature. The cold dried samples were ground and sieve to obtain powder with particle size $\leq 500 \mu \mathrm{m}$ which were used to prepare tea extracts.

\section{Preparation of tea extracts}

To prepare tea extracts, $0.5 \mathrm{~g}$ of each tea powder was introduced into a round bottom flask and extracted twice with $25 \mathrm{~mL}$ of ethanol $80 \%$ on a magnetic stirrer for $30 \mathrm{~min}$. After this, the mixtures were filtered with a Wathman filter paper $\mathrm{N}^{\circ} 1$ and the filtrates were poured in $50 \mathrm{~mL}$ standard flasks and the volume were adjusted to the mark using ethanol $80 \%$. The tea extracts were kept at $4{ }^{\circ} \mathrm{C}$ until analysis.

\section{Evaluation of total phenolics content}

Total phenolic content was determined according to [8]. To $125 \mu \mathrm{L}$ of extract, were added $0.5 \mathrm{~mL}$ of distilled water and $125 \mu \mathrm{L}$ of the solution Folin Ciocalteau: water $(1: 16$, v/v). After 6 min, $1250 \mu \mathrm{L}$ of $7 \%$ sodium carbonate were added and the volume was adjusted to $3 \mathrm{~mL}$ with distilled water and the absorbance measured after 90 min against a blank tube containing extracting solvent at $760 \mathrm{~nm}$. The results were expressed as gram of gallic acid equivalents per $100 \mathrm{~g}$ of dry weight $(\mathrm{g} \mathrm{GAE} / 100 \mathrm{~g} \mathrm{dw})$. All samples were analyzed in triplicates.

\section{Evaluation of total antioxidant activity}

The total antioxidant capacity of tea extracts was determined using the procedure described by [9]. A volume of 20 $\mu \mathrm{L}$ of tea extract was put into a test tube and $280 \mu \mathrm{L}$ of distilled water added. After this, $3 \mathrm{~mL}$ of a reactive solution (0.6 M sulphuric acid, $28 \mathrm{mM}$ sodium phosphate, and $4 \mathrm{mM}$ ammonium molybdate) was added and the tubes were heated or incubated in a water bath at $95{ }^{\circ} \mathrm{C}$ for $90 \mathrm{~min}$. The mixture was then allowed to cool at room temperature and the absorbance was measured at $695 \mathrm{~nm}$ using a spectrophotometer. The total antioxidant capacity was expressed as $\mathrm{mg}$ of Vitamin C equivalents ( $\mathrm{mg}$ Vit C Eq /100 g dw). All samples were analyzed in triplicates.

\section{Statistical analysis}

The models for predicting the total phenolics content $\left(\hat{\mathrm{y}}_{1}\right)$ and antioxidant capacity $\left(\hat{\mathrm{y}}_{2}\right)$ of black tea were expressed individually as:

Equation (1): $\hat{y}_{1}=\alpha_{0}+\alpha_{1} x_{1}+\alpha_{2} x_{2}+\alpha_{11} x_{11}^{2}+\alpha_{22} x^{2}{ }_{22}+\alpha_{12} x_{1} x_{2}$ Equation (2): $\hat{y}_{2}=\beta_{0}+\beta_{1} x_{1}+\beta_{2} x_{2}+\beta_{11} x_{11}^{2}+\beta_{22} x_{22}^{2}+\beta_{12} x_{1} x_{2}$

Where $\hat{y}_{1}$ and $\hat{y}_{2}$ represent the response variables; $\alpha_{0}$ and $\beta_{0}$ the constant coefficients; $\alpha_{1}, \alpha_{2}, \beta_{1}$ and $\beta_{2}$ the coefficients of the linear effects; $\alpha_{11}, \alpha_{22}, \beta_{11}$ and $\beta_{22}$ the coefficients of the squared effects; $\alpha_{12}$ and $\beta_{12}$ the coefficients of the interaction effects.

The response surface graphs of predicted values by models were plotted using Sigma Plot v. 12.5. The values of $\mathrm{R}^{2}$, adjusted- $\mathrm{R}^{2}$ of models were evaluated to check the model adequacies.

Three experimental replicates were performed under optimized conditions and the experimental and predicted values were compared. 


\section{Results and Discussion}

\section{Experimental data}

Fermentation is a critical step in black tea processing. The total antioxidant activity and total phenolics content of black tea are affected by multiple parameters. In this study, the independent variables were the temperature and time of the fermentation. The resulting total and total antioxidant activity as dependent variables for all runs are reported in table 2. The total phenolics content and total antioxidant activity ranged respectively from from $25.63 \pm 1.12$ to $40.36 \pm 0.10 \mathrm{~g} \mathrm{GAE} / 100 \mathrm{~g} \mathrm{dw}$ and $10.55 \pm 0.35$ to $20.61 \pm 0.66 \mathrm{mg}$ Vit C Eq/100 g dw.

Table 2. Experimental design for total phenolics content and for total antioxidant activity

\begin{tabular}{ccccc}
\hline Runs & $\begin{array}{c}\text { Coded and real values for } \\
\text { fermentation temperature }\end{array}$ & $\begin{array}{c}\text { Coded and real values for } \\
\text { fermentation time }\end{array}$ & $\begin{array}{c}\text { Total phenolics } \\
\text { content } \\
(\mathrm{g} \mathrm{GAE} / 100 \mathrm{~g} \mathrm{dw})\end{array}$ & $\begin{array}{c}\text { Total antioxidant } \\
\text { activity } \\
(\mathrm{mg} \mathrm{VitC} \mathrm{Eq} / 100 \mathrm{~g} \mathrm{dw})\end{array}$ \\
\hline 1 & $0\left(35^{\circ} \mathrm{C}\right)$ & $0(2 \mathrm{~h})$ & $31.42 \pm 0.86$ & $12.36 \pm 0.72$ \\
2 & $0\left(35^{\circ} \mathrm{C}\right)$ & $0(2 \mathrm{~h})$ & $31.65 \pm 0.57$ & $12.45 \pm 0.33$ \\
3 & $0\left(35^{\circ} \mathrm{C}\right)$ & $0(2 \mathrm{~h})$ & $30.85 \pm 1.31$ & $12.83 \pm 0.90$ \\
4 & $+1.41\left(4{ }^{\circ} \mathrm{C}\right)$ & $0(2 \mathrm{~h})$ & $25.63 \pm 1.12$ & $10.55 \pm 0.35$ \\
5 & $-1\left(30^{\circ} \mathrm{C}\right)$ & $1(3 \mathrm{~h})$ & $31.38 \pm 0.96$ & $12.67 \pm 0.27$ \\
6 & $0\left(35^{\circ} \mathrm{C}\right)$ & $1(3 \mathrm{~h})$ & $31.52 \pm 0.13$ & $12.42 \pm 0.13$ \\
7 & $+1\left(40{ }^{\circ} \mathrm{C}\right)$ & $0(2 \mathrm{~h})$ & $29.06 \pm 0.37$ & $10.69 \pm 0.17$ \\
8 & $-1.41\left(28^{\circ} \mathrm{C}\right)$ & $-1(1 \mathrm{~h})$ & $32.30 \pm 1.11$ & $14.39 \pm 0.56$ \\
9 & $+1\left(40{ }^{\circ} \mathrm{C}\right)$ & $-1(1 \mathrm{~h})$ & $33.48 \pm 0.76$ & $17.42 \pm 0.27$ \\
10 & $-1\left(30{ }^{\circ} \mathrm{C}\right)$ & $-1.41(35 \mathrm{~min})$ & $34.18 \pm 0.58$ & $15.53 \pm 0.81$ \\
11 & $0\left(35^{\circ} \mathrm{C}\right)$ & & $40.36 \pm 0.10$ & $20.61 \pm 1.85$ \\
\hline
\end{tabular}

\section{Data analysis}

The experimental data were fitted into the second-order polynomial equations and the regression coefficients were calculated, the significance of the coefficients of the models were determined by analysis of variance (ANOVA) as summarized in table 3 .

Table 3. Analysis of variance for the responses of black tea

\begin{tabular}{|c|c|c|c|c|c|c|}
\hline Responses & Source of variation & $\begin{array}{l}\text { Sum of } \\
\text { square }\end{array}$ & $\begin{array}{l}\text { Degree of } \\
\text { freedom }\end{array}$ & $\begin{array}{l}\text { Mean } \\
\text { square }\end{array}$ & f-value & p-value \\
\hline \multicolumn{7}{|c|}{ Total Phenolics Content } \\
\hline & $\mathrm{X}_{1}:$ Time & 131.355 & 1 & 131.355 & 141.99 & 0.0000 \\
\hline & $\mathrm{X}_{2}$ : Temperature & 67.7884 & 1 & 67.7884 & 73.28 & 0.0001 \\
\hline & $\mathrm{X}_{1} \mathrm{X}_{1}$ & 87.2792 & 1 & 87.2792 & 94.35 & 0.0001 \\
\hline & $\mathrm{X}_{1} \mathrm{X}_{2}$ & 5.11446 & 1 & 5.11446 & 5.53 & 0.0570 \\
\hline & $\mathrm{X}_{2} \mathrm{X}_{2}$ & 25.1014 & 1 & 25.1014 & 27.13 & 0.0020 \\
\hline & Lack of fit & 34.7739 & 19 & 1.83021 & 1.98 & 0.2034 \\
\hline & Pure error & 5.5506 & 6 & 0.9251 & & \\
\hline & Corr total & 400.198 & 32 & & & \\
\hline \multicolumn{7}{|c|}{$R^{2}=89.9239 \quad R^{2}$ (adjusted) $=87.1025$} \\
\hline \multicolumn{7}{|c|}{ Total Antioxidant Activity } \\
\hline & $\mathrm{X}_{1}:$ Time & 144.795 & 1 & 144.795 & 474.63 & 0.0000 \\
\hline & $\mathrm{X}_{2}$ : Temperature & 13.8878 & 1 & 13.8878 & 45.52 & 0.0005 \\
\hline & $\mathrm{X}_{1} \mathrm{X}_{1}$ & 54.4506 & 1 & 54.4506 & 178.49 & 0.0000 \\
\hline & $\mathrm{X}_{1} \mathrm{X}_{2}$ & 14.8025 & 1 & 14.8025 & 48.52 & 0.0004 \\
\hline & $\mathrm{X}_{2} \mathrm{X}_{2}$ & 0.0718739 & 1 & 0.0718739 & 0.24 & 0.6446 \\
\hline & Lack of fit & 12.5576 & 19 & 0.660927 & 2.17 & 0.1721 \\
\hline & Pure error & 12.5576 & 6 & 0.30507 & & \\
\hline & Corr total & 250.107 & 32 & & & \\
\hline$R^{2}=94.2472$ & $R^{2}($ adjusted $)=92.6365$ & & & & & \\
\hline
\end{tabular}


Table 3 demonstrates that both fermentation time and temperature have significant linear, interaction and quadratic effects $(p<0.05)$ showing their more significant effect on total phenolics content and total antioxidant activity of black tea [11]. The coefficients of multiple determinations $\left(\mathrm{R}^{2}\right)$ for total phenolics content and total antioxidant activity respectively were 89.9239 and 94.2472 . So, the calculated model was able to explain 89.92 and $94.25 \%$ of the results in case of total phenolics content and total antioxidant activity, respectively. The adequacy of the model to fit the experimental data was verified also by the lack of fit testing; ANOVA for the lack of fit test for all the responses were insignificant ( $p>0.05)$. With a non-significant lack-of-fit $(p \geq 0.05)$ and both $R^{2}$ and $R^{2}$ adj higher than $98 \%$, the analysis indicates that the empirical models fit the experimental data satisfactorily and may be used for prediction purposes [12].

The regression equations obtained for total phenolic content $\left(\hat{\mathrm{y}}_{1}\right)$ and total antioxidant activity $\left(\hat{\mathrm{y}}_{2}\right)$

Equation (1): $\hat{y}_{1}=31.3098-2.33948 x_{1}-1.68063 x_{2}+2.26979 x^{2}{ }_{1}-0.652844 x_{1} x_{2}-1.21725 x_{2}{ }^{2}$ Equation (2): $\hat{y}_{2}=12.547-2.45625 \mathrm{x}_{1}-0.760697 \mathrm{x}_{2}+1.7928 \mathrm{x}_{1}{ }_{1}-1.11065 \mathrm{x}_{1} \mathrm{x}_{2}-0.0651351 \mathrm{x}_{2}{ }^{2}$

\section{Response Surface Methodology}

Response surface methodology is the best approach to assess the effect of different experimental factors (linear, quadratic and interaction effects) on the analytical responses. To visualize the effects of fermentation temperature and time and the relationships between the factors and the response variables, 2D contour plots of the fitted regression equations were generated.

A

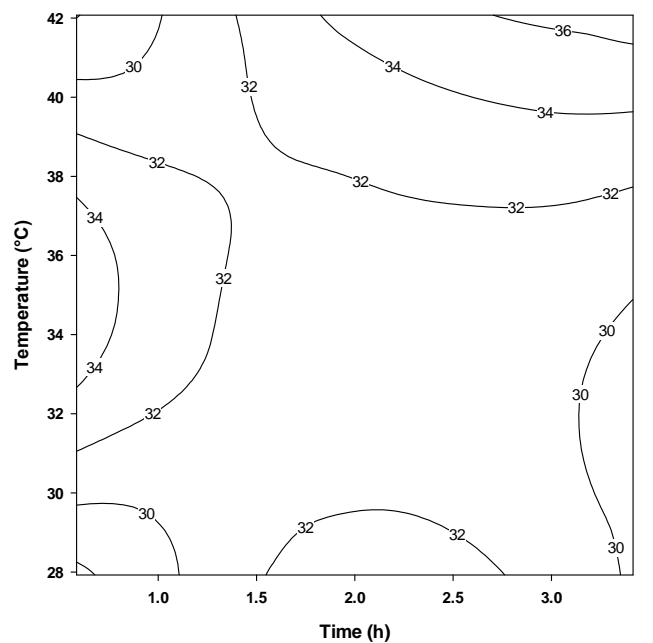

B

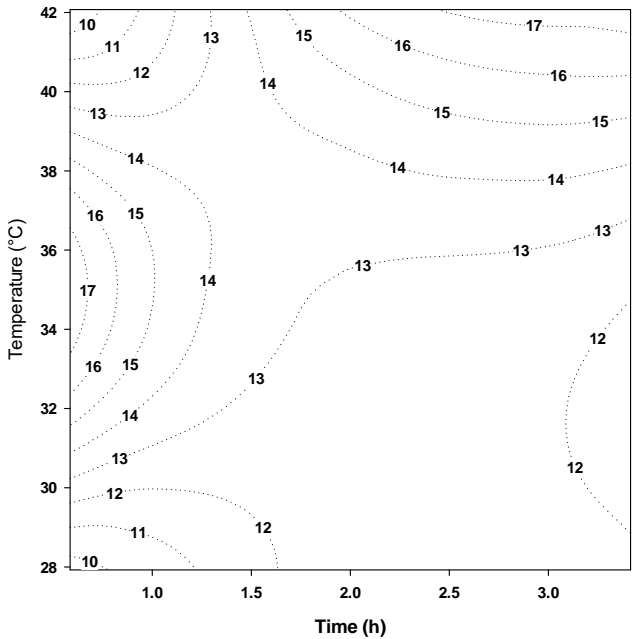

Figure 1. Effect of fermentation time and temperature on total phenolics content (A) and total antioxidant activity (B) of black tea

Figure 1 shows the contour plots of fermentation time and temperature on total phenolics content (a) and total antioxidant activity (b) of black tea. It is noticeable from figure 1a that when fermentation was conducted for 0.5 to $1 \mathrm{~h}$, total phenolics content increased with fermentation temperature between 28 and $38{ }^{\circ} \mathrm{C}$. After $38{ }^{\circ} \mathrm{C}$, total phenolics content started to decrease. When fermentation was conducted for more than $1 \mathrm{~h}$, total phenolics content decreased with fermentation temperature below $38^{\circ} \mathrm{C}$ and increased with fermentation temperature beyond $38^{\circ} \mathrm{C}$. A similar trend was observed in case of total antioxidant activity (figure 1b). Concomitant results were found by [13] who reported temperatures between $30-38^{\circ} \mathrm{C}$ to significantly improve polyphenol contents of bush tea fermented for $30 \mathrm{~min}$. 
In natural form, phenolic compounds are combined or bound with sugar which reduces their availability to organism. During fermentation, proteolytic enzymes hydrolyze complexes of phenolics into soluble-free phenols and other simpler and biologically more active ones $[14,15]$. The bioconversion of the conjugated forms of phenolic compounds into their free forms during fermentation improves their health-linked functionality as antioxidants [16]. However, increasing the fermentation time might allow the microorganisms to use those available compounds as substrates for their growth, thus reducing the sample concentration. Therefore, the fermentation period is critical to ensure optimal breaking down of the compound linkages but not to allow compounds to be substrates for microbial growth [17].

In the other hand, the enzyme polyphenoloxidase is of considerable importance in black tea processing because polyphenoloxidase mainly oxidizes polyphenol to theaflavins. Reference [18] reported that with increase in temperature, the stability of enzyme decreased during fermentation and at $35{ }^{\circ} \mathrm{C}$ it can only be observed $90 \%$ stability of polyphenoloxidase up to $40 \mathrm{~min}$. This decrease in polyphenoloxidase activity during fermentation could explain the increase in total phenolics content observed after fermentation beyond $38{ }^{\circ} \mathrm{C}$ for more than $1 \mathrm{~h}$ since polyphenoloxidase oxidizes the phenolic compounds.

\section{Process Optimization and Confirmatory Study}

A simultaneous optimization using the desirability function was performed in order to maximize the total phenolic compounds and also to maximize the antioxidant capacity of black tea [19]. The optimum fermentation conditions for the present study were at $36{ }^{\circ} \mathrm{C}$ for 35 min which the values for total phenolics content and total antioxidant activity were $38.99 \mathrm{~g} \mathrm{GAE} / 100 \mathrm{~g} \mathrm{dw}$ and $19.74 \mathrm{mg}$ VitC Eq/100 $\mathrm{g} \mathrm{dw}$, respectively.

The experimental values for the same fermentation conditions include total phenolics content and total antioxidant activity of $40.36 \pm 1.99 \mathrm{~g} \mathrm{GAE} / 100 \mathrm{~g} \mathrm{dw}$ and $20.62 \pm 1.85 \mathrm{mg}$ VitC Eq/100 g dw, respectively.

The experimental and predicted values were within the range and did not vary significantly at $5 \%$ level. So, the regression equations obtained can be used to predict the total phenolics content and total antioxidant activity of black tea.

\section{Correlation between Total Phenolics Content and Total Antioxidant Activity}

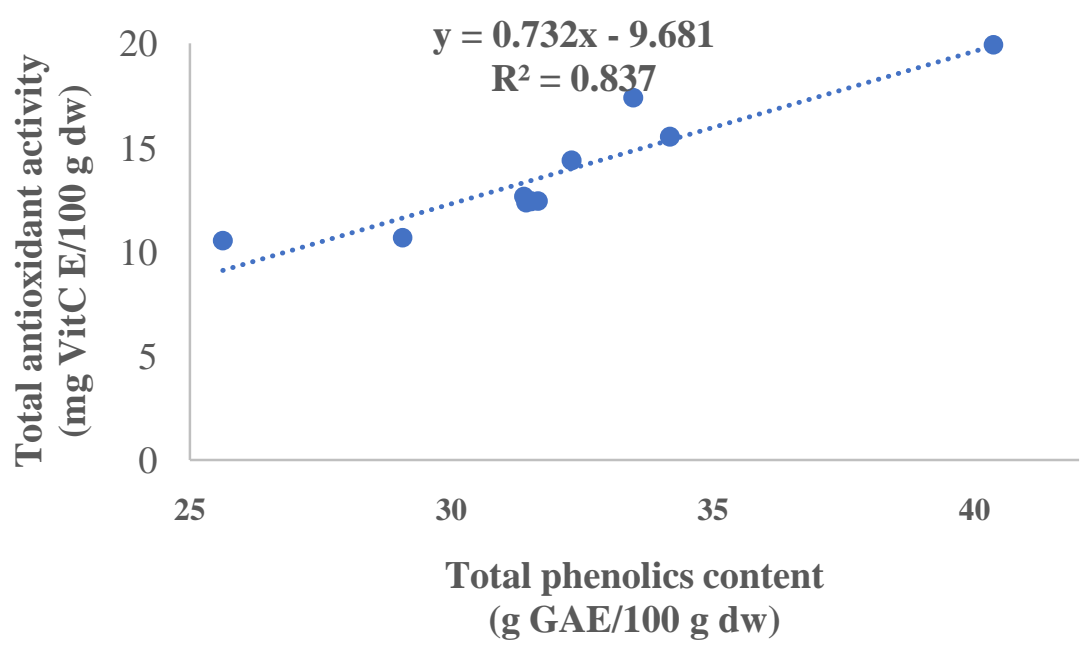

Figure 2. Regression plot between total phenolics content and total antioxidant activity of black tea

Figure 2 showed that total antioxidant activity was strongly correlated $\left(R^{2}=0.84\right)$ to total phenolics content in black tea meaning that black tea possesses antioxidant properties through its chemical components (thearubigins, phenolic acids, catechins, and theaflavins). This strong correlation was earlier reported by [20,21] and implying thus that phenolics possess antioxidant property that provides protection against oxidative stress. 


\section{Conclusion}

Fermentation time and temperature significantly influence the total phenolics and antioxidant activity of black tea. The above study provides an insight on the need of fermenting tea leaves at $36{ }^{\circ} \mathrm{C}$ for $35 \mathrm{~min}$ in order to obtain a functional black tea. It is worthy to mention that the modeling of the total phenolics content and the antioxidant activity of black tea is important because food companies can use this statistical approach as the basis for developing products with a functional claim.

\section{References}

[1] Hodgson J. M. and Croft K. D. (2010). Tea flavonoids and cardiovascular health. Molecular Aspects of Medicine, 31, 495-502.

[2] Sharma V., Gulati A., Ravindranath S. D. and Kumar V. (2005). A simple and convenient method for analysis of tea biochemicals by reverse phase HPLC. Journal of Food Composition and Analysis, 18, 583-594.

[3] Farhoosh, R., Golmovahhed, G.A., Khodaparast, M.H.H., 2007. Antioxidant activity of various extracts of old tea leaves and black tea wastes (Camellia sinensis L). Food Chemistry, 100, 231-236.

[4] Chen N., Bezzina R., Hinch E., Lewandowski P. A., Cameron-Smith D, Mathai M. L., Jois M., Sinclair A. J., Begg D. P., Wark J. D., Weisinger H. S. and Weisinger R. S. (2009). Green tea, black tea, and epigallocatechin modify body composition, improve glucose tolerance, and differentially alter metabolic gene expression in rats fed a high-fat diet. Nutrition Research, 29, 784-793.

[5] Turkmen N., Sari F. and Velioglu Y. S. (2009). Factors affecting polyphenol content and composition of fresh and processed tea leaves. Akademik Gida, 7(6), 29-40.

[6] Borah S. and Bhuyan M., 2005. A computer based system for matching colours during the monitoring tea fermentation. International Journal of Food Science \& Technology, 40, 675-682.

[7] Stewart A. J., Mullen W. and Crozier A., (2005). On-line high-performance liquid chromatography analysis of the antioxidant activity of phenolic compounds in green and black tea. Molecular Nutrition and Food Research, 49, 52-60.

[8] Dewantoo V., Wu X., Adam K. K. and Liu R. H. (2002). Thermal processing enhances the nutritional value of tomatoes by increasing total antioxidant activity. Journal of Agricultural and Food chemistry, 50, 3010-3014.

[9] Prieto P., Pineda M. and Anguilar M., (1999). Spectrophotometric quantitation of antioxidant capacity through the formation of a Phosphomolybdenum Complex: Specific application to the determination of Vitamin E. Analytical Biochemistry, 269, 337-341.

[10] Myers R. H., Montgomery D. C. and Anderson-Cook C. M. (2009). Response surface methodology: Process and product optimization using designed experiments. Third edition, Wiley, New York, $704 \boldsymbol{p}$.

[11] Yang B., Liu X. and Gao Y. (2009) Extraction optimization of bioactive compounds (crocin, geniposide and total phenolic compounds) from Gardenia (Gardenia jasminoides Ellis) fruits with response surface methodology. Innovative Food Science and Emerging Technologies, 10, 610-615.

[12] Bas D. and Boyaci H. (2007). Modeling and optimization I: Usability of response surface methodology. Journal of Food Engineering, 78 (3), 836 - 845.

[13] Hlahla L. N., Mudau F. N. and Mariga I. K. (2010). Effect of fermentation temperature and time on the chemical composition of bush tea (Athrixia phylicoides DC.). Journal of Medicinal Plants Research, 4(9), 824-829.

[14] Shrestha, A.K., Dahal, N.R. and Ndungustse, V. (2010). Bacillus fermentation of soybean: A review. Journal of Food Science and Technology Nepal ,6, 1-9.

[15] Ademiluyi A.O. and Oboh G. (2011). Antioxidant properties of condiment produced from fermented bambara groundnut (Vigna subterranean L. Verdc). Journal of Food Biochemistry, 35, 1145-1160.

[16] Torino M. I., Limón R. I., Martínez-Villaluenga C., Mäkinen S., Pihlanto A., VidalValverde, C. (2013). Antioxidant and antihypertensive properties of liquid and solid state fermented lentils. Food Chemistry, 136(2), 1030-1037.

[17] Ehsan K., Ehsan O., Rudi H. and Jaafar H. Z. E. (2010). Solid state fermentation effects on Pistachio Hulls antioxidant activities presented in the 3rd International Conference for Value Added Agricultural Products. KKU Research Journal, 15 (5), 260-266.

[18] Samanta T., Cheeni V., Das S., Basu R. A., Chandra G. B. and Mitra A. (2015). Assessing biochemical changes during standardization of fermentation time and temperature for manufacturing quality black tea. Journal of Food Science and Technology, 52(4), 2387-2393.

[19] Derringer G. and Suich R. (1980). Simultaneous Optimization of Several Response Variables. Journal of Quality Technology, 12, 214-219.

[20] Dutta A. K., Siddiquee M. A., Hossain S. and Kabir Y. (2013). Finlay green tea possesses the highest in vitro antioxidant activity among the 20 commercially available tea brands of Bangladesh. Malaysian Journal of Pharmaceutical Sciences, 11 (2), 11-20.

[21] Kaur A., Kaur M., Kaur P., Kaur H., Kaur S. and Kaur K. (2015). Estimation and comparison of total phenolics and total antioxidants in green tea and black tea. Global Journal of Bio-science and Biotechnology, 4 (1), 116-120. 